\title{
Genetic effects on the number of spikelets per panicle and fertility restoration in three-line hybrid rice breeding system
}

\author{
Weerachai Matthayatthaworn, Prapa Sripichitt, Tanee Sreewongchai* \\ Department of Agronomy, Faculty of Agriculture, Kasetsart University, Bangkok 10900 Thailand \\ *Corresponding author, e-mail: tanee@yahoo.com
}

Received 1 Jun 2020

Accepted 17 Apr 2021

\begin{abstract}
Number of spikelets per panicle is one of the important characters for rice breeding programs to increase yield potential. The generation mean analysis based on six populations: viz., P1, P2, $\mathrm{F}_{1}, \mathrm{~F}_{2}, \mathrm{BC} 1$, and $\mathrm{BC} 2$ of IR80151A/CH1 with utilizing cytoplasmic-genetic male, was performed. The results showed that dominant gene action was more important than additive type implying that selection in early segregating generations is ineffective and the character could be better exploited through heterosis breeding. Since hybrid rice was used the advantage of the dominant effect through heterosis, due to the role of more favorable dominant genes in $\mathrm{F}_{1}$ hybrid than in both parents. In addition, utilizing cytoplasmic-genetic male sterility in the populations could specify gene control of fertility restoration in hybrid rice. The results revealed that two dominant complementary genes with epistasis controlled the fertility-restoration of wild-abortive cytoplasmic male sterility system (WA-CMS). This information will be useful for future rice breeding in three-line hybrid system.
\end{abstract}

KEYWORDS: complementary epistasis, fertility restoration, generation mean analysis, hybrid rice, number of spikelets per panicle

\section{INTRODUCTION}

Rice is a prime source of food for more than half of the world's population and the world's most important food crop. Out of the total rice produced in the world, Asia produces and consumes more than $90 \%$ [1]. Global population is increasing at an alarming rate. To satisfy the increase of food demands of the increasing population, a $50 \%$ increase in rice production will be required by the year 2050 [2], especially in developing countries of Asia and Africa, where populations have been increasing greatly [3]. Developing cultivars with high yield by increasing genetic potential as well as choosing suitable environment for their growth would be the key for the increment of world rice production [4]. To attain the required yield level, rice varieties with a yield advantage of about $20 \%$ over widely grown cultivars must be developed. Information on genetic parameters of yield and yield component characters can help to determine appropriate breeding procedures [5].

To achieve the required yield level, the target level must be developed with higher yield potential. Rice yield is characterized by some yield compo- nents: number of panicles per plant, number of spikelets per panicle, and 1000-grain weight. Number of spikelets per panicle is a key factor directly associated with rice productivity [6]. Many preliminary studies have been done using generation mean analysis (GMA) to analyze genetic effects $[5,7,8]$. Although several models have been developed for the analysis of generation means so far, it is important to note that these models estimate the relative importance of genetic effects based upon the means of differences from the summation of squared effects for each locus [9]. The GMA has been used to estimate the gene actions controlling the quantitative traits, but knowledge of additive, dominance, and epistasis effects would benefit breeders in designing the most appropriate breeding approaches for developing rice variety. For estimating gene actions, six populations/generations are needed for the GMA, i.e. parent 1 (P1), parent 2 (P2), first filial generation $\left(F_{1}\right)$, second filial generation $\left(F_{2}\right)$, first filial generation of the backcross with recurrent parent 1 (BC1), and first filial generation of the backcross with recurrent parent 2 (BC2).

Hybrid breeding is one of technological tools used to increase potential yield [10]. It can tremen- 
dously improve rice productivity, as effectively demonstrated in China and other Asian countries $[11,12]$. Super-hybrid rice has a very lively future and can make a major contribution to world food security [13]. Cytoplasmic male sterility (CMS) is widely used for hybrid rice production. Three-line hybrid rice system involves the combination of a CMS line (A line), a maintainer line (B line), and a restorer line ( $\mathrm{R}$ line) to restore fertility, and the system has been proved to have considerable value for the development of hybrid varieties [14]. Three types of CMS system are deployed for commercial hybrid production: Wild Abortive (WA), Bao Tai (BT), and Honglian (HL). Among them, the WA type is the most widely used because it is relatively stable, and the pollen sterility is almost complete [15]. The WA-type CMS is sporophytic abortive pollen type [16]. With regards to molecular markers, microsatellite or simple sequence repeat (SSR) markers have also been used by many researchers for the identification of fertility restorer genes and classification of parental gene into categories of $\mathrm{B}$ and $\mathrm{R}$ lines. Two fertility restorer loci are recognized to be concerned in fertility restoration of WA-type CMS in rice $[14,17-20]$.

To achieve the desired genetic improvement towards the development of better cultivar of hybrid rice, it is essential to gather information about the genetic architecture of quantitative traits, including grain yields. The knowledge about the nature and magnitude of gene effects may greatly help in formulating efficient rice breeding strategy. The yield advantage of hybrid rice is primarily due to the increase in number of spikelets per panicle which was shown to be based on genetic effects. The genes were also reported to increase the diameter of the internodes but decrease the number of panicles [21]. The objectives of this study were to estimate gene effects on number of spikelets per panicle by generation mean analysis and to specify gene control of fertility restoration in hybrid rice by utilizing cytoplasmic-genetic male sterility.

\section{MATERIALS AND METHODS}

\section{Plant materials}

The experimental materials were composed of six basic populations (Fig. 1) viz., P1 (parent 1), P2 (parent 2), $\mathrm{F}_{1}(\mathrm{P} 1 \times \mathrm{P} 2), \mathrm{F}_{2}$ (selfing of $\left.\mathrm{F}_{1}\right), \mathrm{BC} 1$ $\left(\mathrm{F}_{1} \times \mathrm{P} 1\right)$ and $\mathrm{BC} 2\left(\mathrm{~F}_{1} \times \mathrm{P} 2\right)$ developed from crosses IR80151A (P1) $\times$ CH1 (P2). These were constructed at Department of Agronomy, Faculty of Agriculture,

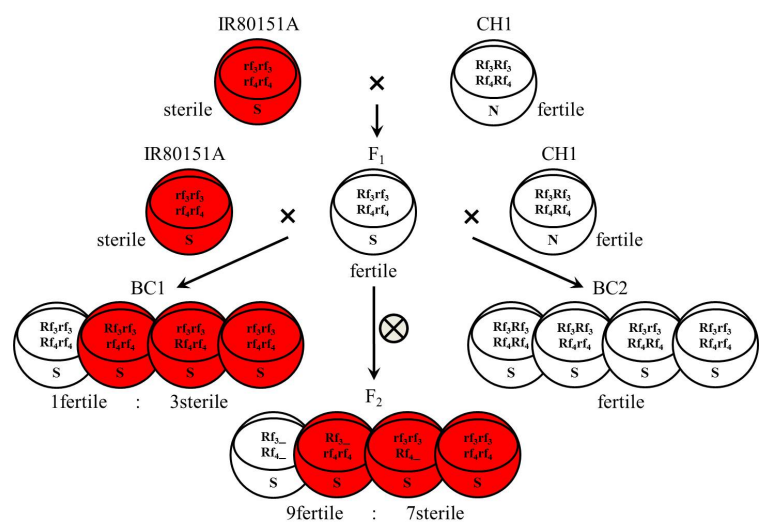

Fig. 1 Phenotype and genotype segregations of fertility restoration in six populations, viz., $\mathrm{P} 1, \mathrm{P} 2, \mathrm{~F}_{1}, \mathrm{~F}_{2}, \mathrm{BC} 1$, and BC2 of IR80151A/CH1. N, normal cytoplasm; S, sterile cytoplasm.

Kasetsart University. The parental lines used in the three-line hybrid rice system were IR80151A, cytoplasmic-genetic male sterile; A line developed by IRRI, and CH1 (restorer line; R line) a Chinese rice variety.

\section{Field experiments}

All the six populations were grown under irrigated field trial at Chai Nat Rice Research Center, Thailand, $15^{\circ} 11^{\prime} \mathrm{N} / 100^{\circ} 08^{\prime} \mathrm{E}$ in 2014 cropping season. The sample sizes were: 20 plants each for P1, P2, and $\mathrm{F}_{1} ; 100$ plants for $\mathrm{F}_{2}$; and 30 plants each for $\mathrm{BC} 1$ and BC2. Individual plants were transplanted at spacing of $20 \mathrm{~cm} \times 20 \mathrm{~cm}$ and grown under the recommended management for rice production. Data on number of spikelets per panicle were collected.

\section{Data analysis}

In the analysis, the weighted regression approach of PBTools software was used. Two full models were fitted to the data. The first one was "mean $=0+\mathrm{m}$ $+\mathrm{a}+\mathrm{d}+\mathrm{aa}+\mathrm{ad}$ ", and other was "mean $=0+\mathrm{m}$ $+\mathrm{a}+\mathrm{d}+\mathrm{aa}+\mathrm{dd}$ " (where [m] general mean, [a] additive effects, [d] dominance effects, [aa] additive by additive effects, [ad] additive by dominance, and [dd] dominance by dominance) [22, 23]. For each model, backward regression procedure was used to obtain the best model. Due to the number of parameters to be estimated in each model, PBTools required at least six generations in the data set. 


\section{RESULTS AND DISCUSSION}

\section{Genetic effects on number of spikelets per panicle}

Genetic analysis using generation mean analysis (GMA) needs six basic populations. The plant materials in this experiment included male sterile line. Therefore, the construction of $\mathrm{F}_{1}$ and $\mathrm{BC} 1$ generations by crossing was done without difficulty since emasculation was not needed. The study of gene effects for number of spikelets per panicle based on set A model 1: mean $0+\mathrm{m}+\mathrm{a}+\mathrm{d}+$ aa + ad (Table 1 ) revealed that additive (a) genetic effects was negative and significant ( $p 0.05)$. Then additive $\times$ dominance (ad) was removed from the model; thus, set A model 2: mean $\sim 0+\mathrm{m}+\mathrm{a}+$ $\mathrm{d}+$ aa resulted in negative and highly significant ( $p 0.01$ ) additive (a) genetic effects. Meanwhile, additive $\times$ additive (aa) and additive $\times$ dominance (ad) were removed from the model; then, set $A$ model 3: mean $\sim 0+\mathrm{m}+\mathrm{a}+\mathrm{d}$ revealed highly significant ( $p 0.01)$ negative and positive additive (a) and dominance (d) genetic effects, respectively. On the one hand, gene effects for number of spikelets per panicle based on set B model 1: mean $\sim \mathrm{m}+$ $\mathrm{a}+\mathrm{d}+\mathrm{aa}+\mathrm{dd}$ (Table 2 ) revealed that additive (a) genetic effect was negative and significant. Then, additive $\times$ additive (aa) effect was removed from the model. Consequently, set B model 2: mean $0+$ $\mathrm{m}+\mathrm{a}+\mathrm{d}+\mathrm{dd}$ showed that additive (a) genetic effect had negative and highly significant, while dominance (d) and dominance $\times$ dominance (dd) genetic effects were positively and negatively significant, respectively. Next, additive $\times$ additive (aa) and dominance $\times$ dominance $(\mathrm{dd})$ effects were removed from the model. Therefore, set B model 3: mean 0 $+\mathrm{m}+\mathrm{a}+\mathrm{d}$ revealed that additive (a) and dominance (d) genetic effects were highly significantly negative and positive, respectively. The results of both set A and set B were significant on model 3 . Furthermore, estimates of gene effects revealed that additive and dominance gene effects were negative and positive, respectively. Thus, gene effects for number of spikelets per panicle based on dominance should be used for hybrid breeding. Heterosis, or hybrid vigor, refers to the superior performance of hybrids relatively to their parents. Therefore, dominance hypothesis was proposed as explanations for the genetic basis of heterosis [24-26].

Performance means of the six populations; viz., P1, P2, $F_{1}, F_{2}, B C 1$, and BC2; of IR80151A/CH1 cross for the number of spikelets per panicle are presented in Table 3 . The observed values of $F_{1}$ and
$\mathrm{F}_{2}$ hybrids were between their parents'. The values of $\mathrm{BC} 1$ and $\mathrm{BC} 2$, compared with that of $\mathrm{F}_{1}$, were decreased and increased, respectively. The predicted mean effect $(\mathrm{m})$ of generations for the parameter number of spikelets per panicle for model 3 in both set $A$ and $B$ were found to be equal since they had the same model "mean $0+\mathrm{m}+\mathrm{a}+\mathrm{d}$ ". The predicted values of $F_{1}$ hybrid and $F_{2}$ were between their parents'. Compared with $\mathrm{F}_{1}$, the predicted values of BC1 and BC2 were decreased and increased, respectively. Furthermore, heterosis (first generation hybrid vigor) was utilized to predict increase of yield potential in development of hybrid rice. When focusing at $\mathrm{F}_{1}$ hybrid, about $16 \%$ hybrid vigor $\left\{\left[\mathrm{F}_{1}-(\mathrm{P} 1+\mathrm{P} 2) / 2\right] /[(\mathrm{P} 1+\mathrm{P} 2) / 2] \times 100\right\}$ was calculated by predicted values in model 3 .

Generally, grain yield depends on yield components. By this, the number of spikelets per panicle plays a major role and is considered as directed sink size. To improve yield potential, thus increasing photosynthetic efficiency was one possible approach recommended plant physiologists $[27,28]$. In practical, the number of spikelets per unit land area was accepted as an index for the development of high grain yield in several cereal crops $[29,30]$. And this can be exercised either by increasing the number of panicles, or the number of spikelets per panicle, or both [31]. Therefore, improvement in number of spikelets per panicle might be sufficient to increase the yield potential of the IR80151A/CH1 cross by hybrid breeding.

Number of spikelets per panicle is one of the important traits for rice breeding programs to increase yield potential, and it is useful for developing restorer line ( $\mathrm{R}$ line) [32]. Generation mean analysis, based on six populations, viz., P1, P2, F , F 2 , BC1, and BC2 of IR80151A/CH1 and cytoplasmic-genetic male sterility, was performed. The results indicated the presence of significantly negative additive gene effects, while the dominant gene effect was positive. The dominant gene action was more distinctive than the additive type, indicating that selection in early segregating generations is ineffective; and the character could be better exploited through heterosis breeding. All types of interaction gene effects were found non-significant, indicating less importance of interaction gene effects on the number of spikelet per panicle. The optimal combination of genes regulating the number of spikelets per panicle and genes controlling other yield-related traits needs to be explained in field experiments [21]. However, the present study revealed that dominant gene action contributed a major effect on the number of 
Table 1 Estimates of gene effects on number of spikelets per panicle based on set A full model: mean $\sim 0+m+a+d$ + aa + ad.

\begin{tabular}{lrrr}
\hline Effect & Estimate & Std. Error & $t$-value \\
\hline Set A model 1: mean 0 + m + a + d + aa + ad & 255.15 & & $25.30^{* *}$ \\
Mean (m) & -42.56 & 10.09 & $-12.97^{*}$ \\
Additive (a) & 24.52 & 3.28 & $1.63^{\text {ns }}$ \\
Dominance (d) & -10.90 & 15.01 & $-1.03^{\text {ns }}$ \\
Additive $\times$ additive (aa) & 3.74 & 10.64 & $0.19^{\text {ns }}$ \\
Additive $\times$ dominance (ad) & & 19.69 & $35.16^{* *}$ \\
Set A model 2: mean 0 + m + a + d + aa & 255.09 & & $-19.09^{* *}$ \\
Mean (m) & -42.35 & 7.26 & $2.26^{\text {ns }}$ \\
Additive (a) & 24.45 & 2.22 & $-1.43^{\text {ns }}$ \\
Dominance (d) & -10.91 & 10.80 & 7.66 \\
Additive $\times$ additive (aa) & & & $96.13^{* *}$ \\
Set A model 3: mean 0 + m + a + d & 245.24 & 2.55 & $-16.56^{* * *}$ \\
Mean (m) & -42.53 & 2.57 & $7.13^{* *}$ \\
Additive (a) & 38.35 & 5.38 & \\
Dominance (d) & &
\end{tabular}

ns, non-significant; *, significant at 0.05 probability level; **, significant at 0.01 probability level.

Table 2 Estimates of gene effects for number of spikelets per panicle based on set B full model: mean $\sim 0+\mathrm{m}+\mathrm{a}+\mathrm{d}$ + aa + dd.

\begin{tabular}{|c|c|c|c|}
\hline Effect & Estimate & Std. Error & $t$-value \\
\hline \multicolumn{4}{|c|}{ Set B model 1: mean $\sim 0+m+a+d+a a+d d$} \\
\hline Mean (m) & 235.87 & 12.92 & $18.26^{*}$ \\
\hline Additive (a) & -41.93 & 1.66 & $-25.32^{*}$ \\
\hline Dominance $(d)$ & 78.79 & 34.17 & $2.31^{\mathrm{ns}}$ \\
\hline Additive $\times$ additive (aa) & 7.81 & 12.76 & $0.61^{\mathrm{ns}}$ \\
\hline Dominance $\times$ dominance $(\mathrm{dd})$ & -36.81 & 22.50 & $-1.63^{\mathrm{ns}}$ \\
\hline \multicolumn{4}{|c|}{ Set B model 2: mean $\sim 0+\mathrm{m}+\mathrm{a}+\mathrm{d}+\mathrm{dd}$} \\
\hline Mean (m) & 243.70 & 1.44 & $168.94^{* *}$ \\
\hline Additive (a) & -42.04 & 1.36 & $-30.82^{* *}$ \\
\hline Dominance (d) & 58.61 & 7.40 & $7.92^{*}$ \\
\hline Dominance $\times$ dominance $(\mathrm{dd})$ & -24.46 & 8.25 & $-2.96^{*}$ \\
\hline \multicolumn{4}{|c|}{ Set B model 3: mean $\sim 0+\mathrm{m}+\mathrm{a}+\mathrm{d}$} \\
\hline Mean (m) & 245.24 & 2.55 & $96.13^{* *}$ \\
\hline Additive (a) & -42.53 & 2.57 & $-16.56^{* *}$ \\
\hline Dominance $(\mathrm{d})$ & 38.35 & 5.38 & $7.13^{* *}$ \\
\hline
\end{tabular}

ns, non-significant; *, significant at 0.05 probability level; **, significant at 0.01 probability level.

Table 3 Observed and predicted values of generation means for number of spikelets per panicle.

\begin{tabular}{|c|c|c|c|c|c|c|c|}
\hline \multirow[t]{3}{*}{ Generation } & \multirow{3}{*}{$\begin{array}{c}\text { Observed } \\
\text { value }\end{array}$} & \multicolumn{6}{|c|}{ Predicted value } \\
\hline & & \multicolumn{3}{|c|}{ Set A } & \multicolumn{3}{|c|}{ Set B } \\
\hline & & Model 1 & Model 2 & Model 3 & Model 1 & Model 2 & Model 3 \\
\hline P1 & 201 & 202 & 202 & 203 & 202 & 202 & 203 \\
\hline P2 & 286 & 287 & 287 & 288 & 286 & 286 & 288 \\
\hline $\mathrm{F}_{1}$ & 278 & 280 & 280 & 284 & 278 & 278 & 284 \\
\hline $\mathrm{F}_{2}$ & 266 & 267 & 267 & 264 & 266 & 267 & 264 \\
\hline BC1 & 251 & 244 & 243 & 243 & 247 & 246 & 243 \\
\hline BC2 & 288 & 285 & 286 & 286 & 289 & 288 & 286 \\
\hline
\end{tabular}


Table 4 Segregation for fertility restoration in six rice populations of IR80151A/CH1.

\begin{tabular}{lccc}
\hline Population & No. of plant & Fertility:sterility & Chi square \\
\hline P1 & 20 & $0: 20$ & \\
P2 & 20 & $20: 0$ & \\
F1 & 20 & $20: 0$ & \\
F2 & 100 & $55: 45$ & $9: 7^{\text {ns }}$ \\
BC1 & 29 & $4: 25$ & $1: 3^{\text {ns }}$ \\
BC2 & 32 & $32: 0$ & \\
\hline
\end{tabular}

ns, non-significant.

spikelets per panicle, and hybrid breeding would be a suitable and rapid mean to increase grain yield.

\section{Genetic control of fertility restoration}

Segregation for fertility restoration of the six populations; viz., P1, P2, $F_{1}, F_{2}, B C 1$, and $\mathrm{BC} 2$ of IR80151A/CH1 cross; is presented in Table 4. Four populations ( $\mathrm{P} 1, \mathrm{P} 2, \mathrm{~F}_{1}$, and $\mathrm{BC} 2$ ) were not segregating populations, while the other two $\left(\mathrm{F}_{2}\right.$ and BC1) were. Thus, to analyze the inheritance behavior of male fertile gene, two different populations were used in the segregation analysis. There have been some reports showing that two dominant genes control the fertility restoration of WA cytoplasm $[14,17-20]$. In general, two genes in $\mathrm{F}_{2}$ population will express four phenotypes with the ratio of 9:3:3:1. Interestingly, the inheritance of fertility restoration in this study revealed that $\mathrm{F}_{2}$ population contained two phenotypes with a ratio of (fertility and sterility) 9:7. Moreover, the segregation ratio of (fertility and sterility) 1:3 was found in BC1 population. Thus, the result indicated that fertility restoration was controlled by two genes with epistasis (the effect of one gene may change according to the presence or absence of another gene or other genes). A clear possibility that the fertility restoration of WA cytoplasm was controlled by two dominant genes was formerly reported [33, 34]. In addition, BC2 did not segregate, but all plants showed fertility. This suggests that two dominant genes seem to control the fertility restoration as described previously [35].

Geneetic control of fertility restoration is important for hybrid rice breeding in three-line system. The IR80151A/CH1 cross was used in this study. Based on fertility status, plants are classified into two groups, fertile and sterile. IR80151A was developed by IRRI and was used as female parent for three-line hybrid rice system in Thailand [36]. The results revealed that two dominant complementary genes with epistasis controlled the fertility-restorer gene of wild-abortive cytoplasmic male sterility system (WA-CMS). According to [37], two dominant genes, $R f 3$ and Rf4; which are located on chromosome 1 and 10, respectively; are important for fertility restoration in many restorer lines of WA-CMS types. The $\mathrm{F}_{1}$ hybrid showed fertile plants since it is heterozygous, and the two genes are present in the $\mathrm{F}_{1}$ (Fig. 1). The BC1 population was generated by IR80151A/F $F_{1}$ and it showed segregation into fertile and sterile plants in $1: 3$ ratios. The fertile plants showed genotype of $F_{1}$, but the sterile plants did not have both dominant alleles. For BC2 population, they were created with $\mathrm{F}_{1} / \mathrm{CH} 1$ and all plants were fertile. All of them got at least one dominant allele from each of the two genes. In addition, the fertility and sterility ratio in $F_{2}$ population segregation was 9:7. This ratio was accepted for two genes with complementary epistasis (at least one dominant allele from each of the two genes needed for expression of the final phenotype). Similar results were demonstrated using three indica/japonica restorers and three WA-type CMS lines showing that two or three major genes controlled fertility restoration with epistasis interactions differing from cross to cross [38]. Study results also indicated different types of gene interactions, such as recessive epistasis, semi-epistasis [39], epistasis with incomplete dominance [40], and epistasis with complete dominance [41]. On the basis of the aforementioned results, a clear model of the fertility restoration genetics would be beneficial to rice breeders in designing breeding procedures for improving the parental lines.

\section{CONCLUSION}

The findings of the present study evident that the number of spikelets per panicle estimated through generation mean analysis was controlled by dominant gene action. Therefore, improvement in number of spikelets per panicle may be sufficient to increase the yield potential by utilizing hybrid vigor. Practicing hybrid breeding may eventually lead to increase in number of spikelets per panicle and yield increment. In addition, two dominant complementary genes with epistasis control the fertility-restoration of wild-abortive cytoplasmic male sterility system (WA-CMS). The information would be useful for future hybrid rice breeder to design breeding procedures to improve the parental lines. 
Acknowledgements: This work was supported by hybrid rice breeding project, Department of Agronomy, Faculty of Agriculture, Kasetsart University from Agricultural Research Development Agency (public organization), Thailand. The technical help of Assoc. Prof. Dr. Rungsarid Kaveeta is highly appreciated.

\section{REFERENCES}

1. Khush GS (2005) What it will take to feed 5.0 billion rice consumers in 2030. Plant Mol Biol 59, 1-6.

2. Alexandratos N, Bruinsma J (2012) World Agriculture Towards 2030/2050: The 2012 Revision. 12-03 Rome: FAO, ESA working paper.

3. Seck PA, Diagne A, Mohanty S, Wopereis MCS (2012) Crops that feed the world 7: rice. Food Security 4, 7-24.

4. Nakwilai P, Cheabu S, Narumon P, Saensuk C, Arikit S, Malumpong C (2020) Evaluation of japonica rice (Oryza sativa L.) varieties and their improvement in terms of stability, yield and cooking quality by pureline selection in Thailand. ScienceAsia 46, 157-168.

5. Kumar PS, Saravanan K, Sabesan T (2017) Generation mean analysis for yield and grain quality characters in rice (Oryza sativa L.). Plant Arch 17, 557-560.

6. Bai X, Wu B, Xing Y (2012) Yield-related QTLs and their applications in rice genetic improvement. $J$ Integr Plant Biol 54, 300-311.

7. Hasib KM, Ganguli PK, Kole PC (2002) Genetic analysis of some quantitative characters in aromatic rice involving induced mutants. Trop Agric Res Ext 5, 1-6.

8. Samineni S, Gaur PM, Colmer TD, Krishnamurthy L, Kadambot VV, Siddique HM (2011) Estimation of genetic components of variation for salt tolerance in chickpea using the generation mean analysis. Euphytica 182, 73-86.

9. Hallauer AR, Carena MJ, Filho JBM (2011) Quantitative Genetics in Maize Breeding, Springer, New York, USA.

10. Virmani SS (1994) Heterosis and Hybrid Rice Breeding, Springer-Verlag Herlin, Heidelberg.

11. Matthayatthaworn W, Sripichitt P, Phumichai C, Rungmekarat S, Uckarach S, Sreewongchai T (2011) Development of specific simple sequence repeat (SSR) markers for non-pollen type thermo-sensitive genic male sterile gene in rice (Oryza sativa L.). Afr J Biotechnol 10, 16437-16442.

12. Sreewongchai T, Matthayatthaworn W, Phumichai C, Sripichitt P (2014) Introgression of gene for nonpollen type thermo-sensitive genic male sterility to Thai rice cultivars. Rice Science 21, 123-126.

13. Yuan L (2017) Progress in super-hybrid rice breeding. Crop J 5, 100-102.

14. Kumar P, Sharma VK, Prasad BD (2015) Characterization of maintainer and restorer lines for wild abortive cytoplasmic male sterility in indica rice (Oryza sativa
L.) using pollen fertility and microsatellite (SSR) markers. Aust J Crop Sci 9, 384-393.

15. Shinjyo C, Omura T (1966) Cytoplasmic-genetic male sterility in cultivated rice, Oryza sativa L. I Fertilities of $\mathrm{F}_{1}, \mathrm{~F}_{2}$ and offsprings obtained from their mutual reciprocal backcrosses and segregation of completely male sterile plants. Japan J Breed 16, 179-180.

16. Huang J, Hu J, Xu X, Li S, Yi P, Yang D, Ren F, Liu $X$, et al (2003) Fine mapping of the nuclear fertility restorer gene for HL cytoplasmic male sterility in rice. Bot Bull Acad Sin 44, 285-289.

17. Sattari M, Kathiresan A, Gregorio GB, Hernandez JE, Nas TM, Virmani SS (2007) Development and use of a two-gene marker-aided selection system for fertility restorer genes in rice. Euphytica 153, 35-42.

18. Bazrkar L, Ali AJ, Babaeian NA, Ebadi AA, Allahgholipour M, Kazemitabar K, Nematzadeh G (2008) Tagging of four fertility restorer loci for wild abortive-cytoplasmic male sterility system in rice (Oryza sativa L.) using microsatellite markers. Euphytica 164, 669-677.

19. Sheeba NK, Viraktamath BC, Sivaramakrishnan S, Gangashetti MG, Khera P, Sundaram RM (2009) Validation of molecular markers linked to fertility restorer gene(s) for WA-CMS lines of rice. Euphytica 167, 217-227.

20. Revathi P, Medoju P, Singh AK, Sundaram RM, Raju S, Senguttuvel P, Kemparaju KB, Hariprasad AS, et al (2013) Efficiency of molecular markers in identifying fertility restoration trait of WA-CMS system in rice. Indian J Genet 73, 89-93.

21. Fukushima A, Ohta H, Yokogami N, Tsuda N, Yoshida A, Kyozuka J, Maekawa M, (2017) Effects of genes increasing the number of spikelets per panicle, TAW1 and APO1, on yield and yield-related traits in rice. Plant Prod Sci 20, 485-489.

22. Gamble EE (1962) Gene effects in corn (Zea mays L.). I. Selection and relative importance of gene effects for yield. Can J Plant Sci 42, 339-348.

23. Gamble EE (1962) Gene effects in corn (Zea mays L.). II. Relative importance of gene effects for plant height and certain component attributes of yield. Can J Plant Sci 42, 349-358.

24. Bruce AB (1910) The Mendelian theory of heredity and the augmentation of vigor. Science 32, 627-628.

25. Keeble F, Pellew C (1910) The mode of inheritance of stature and of time of flowering in peas (Pisum sativum). $J$ Genet 1, 47-56.

26. Jones DF (1917) Dominance of linked factors as a means of accounting for heterosis. Genetics 2, 466-479.

27. Evans LT (1972) Storage capacity as a limitation on grain yield. In: Rice Breeding, International Rice Research Institute, Los Baños, Philippines, pp 499-511.

28. Yoshida S (1972) Physiological aspects of grain yield. Ann Rev Plant Physiol 23, 437-464. 
29. Fischer RA (1983) Wheat. In: Potential Productivity of Field Crops Under Different Environments, International Rice Research Institute, Los Baños, Philippines, pp 129-154.

30. Takeda T (1984) Physiological and ecological characteristics of high yielding varieties of lowland rice. In: Proceeding International Crop Science Symposium, Fukuoka, Japan.

31. Peng S, Khush GS, Cassman KG (1994) Breaking the yield barrier: Evolution of the new plant ideotype for increased yield potential. In: Cassman KG (ed) Proceeding of Workshop on Rice Yield Potential in Favorable Environments, International Rice Research Institute, Los Baños, Philippines, pp 5-20.

32. Koide Y, Fujita D, Tagle AG, Sasaki K, Ishimaru T, Fukuta Y, Kobayashi N (2013) QTL for spikelet number from a high-yielding rice variety, Hoshiaoba, detected in an introgression line with the genetic background of an indica rice variety, IR64. Euphytica 192, 97-106.

33. Pradhan SB, Jachuck PJ (1999) Genetics of fertility restoration of elite lines for different cytoplsmic male sterile sources in rice. Oryza 36, 374-376.

34. Sridhara S, Vidhyachandra B, Kulkarni RS, Prasanna HC, Shetty V (1999) Genetics of fertility restoration for CMS line in rice (Oryza sativa L.). Mysore J Agr Sci 32, 107-110.
35. Bagheri N, Jelodar NB (2011) Genetics and combining ability of fertility restoration of 'wild abortive' cytoplasmic male sterility in rice. Afr J Biotechnol 10, 9314-9321.

36. Seesang J, Sripichitt P, Sreewongchai T (2014) Heterosis and inheritance of fertility-restorer genes in rice. ScienceAsia 40, 48-52.

37. Yao FY, Xu CG, Yu SB, Li JX, Gao YJ, Li XH, Zhang Q (1997) Mapping and genetic analysis of two fertility restorer loci in the wild-abortive cytoplasmic male sterility system of rice (Oryza sativa L.). Euphytica 98, 183-187.

38. Hossain MS, Singh AK, Fasih Z, (2010) Genetics of fertility restoration of 'WA'-based cytoplasmic male sterility system in rice (Oryza sativa) using indica/japonica derivative restorers. ScienceAsia 36, 94-99.

39. Sawant DS, Kunkerkar RL, Shetye VN, Shirdhankar MM (2006) Inheritance of fertility restoration of five sources of cytoplasmic male sterility in rice (Oryza sativa L.). Ann Agric Res New Ser 27, 133-138.

40. Sarkar CKG, Zaman FU, Singh AK (2002) Genetics of fertility restoration of 'WA' based cytoplasmic male sterility system in rice (Oryza sativa L.) using basmati restorer lines. Indian J Genet 62, 305-308.

41. Sohu VS, Phul PS (1995) Inheritance of fertility restoration of three source of cytoplasmic male sterility in rice. $J$ Genet Breed 49, 93-96. 